Article

\title{
Designer Biochars Impact on Corn Grain Yields, Biomass Production, and Fertility Properties of a Highly-Weathered Ultisol
}

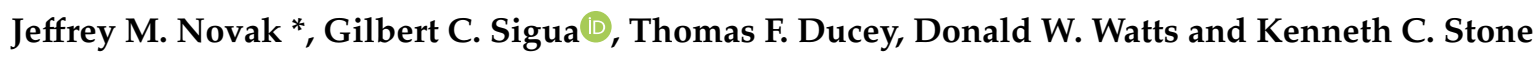 \\ United States Department of Agriculture, Agricultural Research Service, Coastal Plains, Soil, Water, and Plant \\ Research Center, 2611 West Lucas Street, Florence, SC 29501, USA; gilbert.sigua@ars.usda.gov (G.C.S.); \\ tom.ducey@ars.usda.gov (T.F.D.); don.watts@ars.usda.gov (D.W.W.); ken.stone@ars.usda.gov (K.C.S.) \\ * Correspondence: Jeff.Novak@usda.gov; Tel.: +1-843-669-5203
}

Received: 24 April 2019; Accepted: 1 June 2019; Published: 4 June 2019

check for updates

\begin{abstract}
There are mixed reports for biochars' ability to increase corn grain and biomass yields. The objectives of this experiment were to conduct a three-year corn (Zea mays L.) grain and biomass production evaluation to determine soil fertility characteristics after designer biochars were applied to a highly weathered Ultisol. The amendments, which consisted of biochars and compost, were produced from $100 \%$ pine chips (PC); 100\% poultry litter (PL); PC:PL 2:1 blend; PC mixed 2:1 with raw switchgrass (Panicum virgatum; rSG) compost; and 100\% rSG compost. All treatments were applied at 30,000 kg/ha to a Goldsboro loam sandy (Fine-loamy, siliceous, sub-active, thermic Aquic Paleudult). Annual topsoil samples were collected in 5-cm depth increments (0 to 15-cm deep) and $\mathrm{pH}$ was measured along with Mehlich 1 phosphorus (M1 P) and potassium (M1 K) contents. After three years of corn production, there was no significant improvement in the annual mean corn grain or biomass yields. Biochar, which was applied from PL and PC:PL 2:1 blend, significantly increased M1 P and M1 K concentrations down to 10-cm deep, while the other biochar and compost treatments showed mixed results when the soil $\mathrm{pH}$ was modified. Our results demonstrated that designer biochar additions did not accompany higher corn grain and biomass productivity.
\end{abstract}

Keywords: corn production; designer biochars; soil fertility; Ultisol

\section{Introduction}

Biochar is used as an amendment in agricultural soils to improve their physical characteristics [1-4] and to bolster important fertility properties [5-8]. Biochars' ability to improve soil fertility is explained by the composition of organic compounds, which rebuilds soil organic carbon (SOC) levels [9-11] and ash material, which are comprised of important plant macro- and micro-nutrients [12-14].

For farmers and land managers to be able utilize biochar as a soil amendment, there must be a financial realization that crop or biomass yields are significantly improved. Several reviews [15-17] have reported that, while the overall crop productivity improvement is around $10 \%$, positive crop responses are better demonstrated by adding biochar to acidic, nutrient-poor soils in tropical regions, than in soils in temperate regions. Furthermore, the variability of biochar performance for improving crop yields was further demonstrated by Spokas et al. [18], who reported that biochar caused positive yield increases in $50 \%$ of examined studies, but in the remaining $50 \%$, there was no improvement or a decrease in crop yields. More recent examples where biochar was applied to field soils, that did not significantly improve corn yields, were reported $[19,20]$. In these studies, the test sites were in temperate climatic regions that may explain the lack of significant corn grain yield improvements.

The literature has shown that biochar chemical and physical properties can be quite variable because of feedstock choice differences [12,21], pyrolysis temperature selection [22,23], and post 
production variance in supply chain management and transportation [24]. Thus, biochar variability can cast some confusion on biochar management decisions. Therefore, an alternate paradigm for biochar usage was introduced [6,25], whereby biochar properties would be matched to correct specific soil fertility deficiencies (i.e., low $\mathrm{pH}$, poor plant nutrient levels, etc.). Novak et al. [6] coined the technology "designer biochar". Designer biochars are produced so they have specific chemical (i.e., $\mathrm{pH}$, nutrient contents, etc.) and physical (i.e., pellets, particle size, etc.) properties through the choice of feedstock, pyrolytic temperatures, and biochar morphology $[25,26]$. This concept has been adjudicated for biochar production by others [27-29], in order to adjust $\mathrm{pH}$ in a calcareous soil [7] and raise winter wheat yields [30].

In many other biochar evaluation studies, there is minimal concern of matching the right biochar to the specific soil problem. In contrast to this approach, our study is unique because designer biochars, used in this study, were selected to target specific soil physico-chemical deficiencies. The Goldsboro soil has deficiencies related to crop production that includes, poor water retention, low SOC, and nutrient contents. We based the designer biochar properties on prior laboratory results, using sandy soils that showed improvement in soil nutrient status [6]; SOC contents [31]; moisture retention [32]; and rebalancing $P$ contents in manure-based biochars [26]. Here, designer biochars were created using commercially purchased biochars, produced from poultry litter (PL) and lodgepole pine chip (PC) feedstocks, and in blends using raw (unpyrolyzed) switchgrass compost (rSG). The biochars were mixed with a compost made from raw switchgrass, since other investigations that had used biochar, mixed with compost, found improved corn grain yields in Australia field plots [33] and with improved wheat yields in China [34].

The objectives of this three-year field experiment were to evaluate the effectiveness of these designer biochars by, 1) improving soil fertility characteristics (i.e., $\mathrm{pH}$, soil Mehlich $1 \mathrm{P}$ and K contents), and 2) increasing corn (Zea mays, L.) grain yields and biomass production.

\section{Materials and Methods}

\subsection{Site Characteristics and Soil Properties}

The 2-ha field site, used in this study, is located on the property of the United States Department of Agriculture-Agricultural Research Service-Coastal Plain Soil, Water, and Plant Research Center, located in Florence, South Carolina, USA ( $34^{\circ} 14^{\prime} 38^{\prime \prime} \mathrm{N}$ and $\left.79^{\circ} 48^{\prime} 45.3^{\prime \prime} \mathrm{W}\right)$. Over 50 years of farming, the field has been under row crop production, including corn (Zea Mays L.), soybeans (Glycine max), and an assortment of vegetables (i.e., tomato, strawberry, etc.) crops. For production of these crops, the field was cultivated using either, conservation (deep tilled to 30 to $40 \mathrm{~cm}$ ) and conventional (disking to incorporate surface residue to about $10 \mathrm{~cm}$ deep) tillage practices.

Soil in the field is classified as a Goldsboro loamy sand (Fine-loamy, siliceous, sub-active, thermic Aquic Paleudult). The profile characteristics for the Goldsboro series include, a thin Ap horizon (0 to $20 \mathrm{~cm}$ deep), and a shallow E horizon (20 to 30-cm below surface) overlying a series of well-developed $\mathrm{Bt}$ argillic horizons, that are expressed down to about $165-\mathrm{cm}$. The $\mathrm{C}$ horizon occurs deeper than $165-\mathrm{cm}$, is sandy to clayey in texture, and contains distinctive redoximorphic features. The series are moderately-well drained and exhibit masses of oxidized yellow and red colored iron mottles/concretions in the Bt horizons. The series occur in the middle coastal plain region and the parent material consists of marine deposits, interlaced with fluvio-marine sediments [35].

\subsection{Designer Biochar Preparation and Characterization}

The PC and PL biochars were available commercially. Lodgepole pine (Pinus contorta) chips were transformed into biochar using a two-stage process as described [36]. In the first stage of the pyrolysis process, the chips were exposed to temperatures between 500 and $700{ }^{\circ} \mathrm{C}$ for $<1$ min under a very low $\mathrm{O}_{2}$ atmosphere. In the second stage, the chips were furthered carbonized in an anaerobic environment at temperatures between 300 and $550{ }^{\circ} \mathrm{C}$ for approximately $15 \mathrm{~min}$, then removed and 
allowed to air-cool. The PL biochar was produced using a gasification process employing a fixed-bed pyrolizer programed for conditions (temperature and hold time) that are propriety. The switch-grass feedstock was obtained from plots grown at the Clemson University Pee Dee Research and Education Center, Darlington, South Carolina, USA. The switchgrass was processed using a mechanical grinder to produce 6-mm sized flakes. The bulk material was allowed to compost for 1 week prior to application.

All five amendments were characterized for their $\mathrm{pH}$ in a 1:2 (w/w) ratio with deionized water [26]. Additionally, all five amendments were characterized by ultimate analysis, using ASTM method D 3176 ([37]; Hazen Research, Inc., Golden, Colorado, USA] for their ash, fixed C, volatile matter, C, H, $\mathrm{O}, \mathrm{N}$ and $\mathrm{S}$ contents (Table 1 ). Their molar $\mathrm{H} / \mathrm{C}$ and $\mathrm{O} / \mathrm{C}$ ratios were calculated from the elemental analysis (Table 1). The total concentrations of $\mathrm{P}, \mathrm{K}, \mathrm{Cu}$ and $\mathrm{Zn}$ concentrations were determined on the ash fraction in 100\% PC and 100\% PL biochar amendments by first ashing the samples at $600{ }^{\circ} \mathrm{C}$, digesting the ash using method SW866 [37], and then quantifying metal content using ICP-OES by Hazen Research, Inc. The P, K, Cu, and Zn concentrations in the switchgrass compost were determined using acid digestion by the Clemson University Agricultural Service Laboratory (https://www.clemson.edu/public/regulatory/ag-srvc-lab).

Table 1. Designer biochar and compost characteristics (PC = pine chip; PL = poultry litter, rSG $=$ raw switchgrass as compost; nd = not determined).

\begin{tabular}{cccccc}
\hline Parameter (\%) & $\mathbf{1 0 0} \% \mathbf{P C}$ & $\mathbf{1 0 0} \% \mathbf{P L}$ & PC:PL 2:1 & PC:rSG 2:1 & rSG \\
\hline $\mathrm{C}$ & 88.5 & 33.2 & 74.4 & 76.8 & 51.9 \\
$\mathrm{H}$ & 1.64 & 2.23 & 2.51 & 3.49 & 5.61 \\
$\mathrm{O}$ & 5.91 & 4.21 & 5.95 & 16.27 & 37.7 \\
$\mathrm{~N}$ & 0.49 & 3.6 & 1.41 & 0.34 & 0.35 \\
$\mathrm{~S}$ & 0.011 & 2.6 & 0.48 & 0.02 & 0.01 \\
$\mathrm{P}$ & $0.025^{+}$ & $3.36+$ & nd & nd & 0.07 \\
$\mathrm{~K}$ & $0.301^{\dagger}$ & $7.23+$ & nd & nd & 0.29 \\
$\mathrm{Cu}$ & $0.019^{+}$ & $0.16+$ & nd & nd & 0.0007 \\
Zn & $0.008^{+}$ & $0.100+$ & nd & nd & 0.0016 \\
Ash & 3.46 & 54.1 & 15.2 & 3.07 & 4.38 \\
Fixed C & 85.7 & 16.5 & 67.6 & 62.7 & 17.4 \\
Volatile matter & 10.8 & 29.4 & 17.2 & 34.2 & 78.2 \\
pH & 7.8 & 9.1 & 9.1 & 7.3 & 5.4 \\
O/C & 0.05 & 0.094 & 0.059 & 0.15 & 0.54 \\
H/C & 0.22 & 0.81 & 0.4 & 0.54 & 1.29 \\
\hline \multicolumn{5}{r}{ determined on an ash-basis. }
\end{tabular}

\subsection{Field Plot Establishment, Soil Sampling, Biochar Application, Corn Management, and Precipitation Recordings}

In December 2015, twenty-four plots were established in a randomized complete block design, that allowed for $n=4$ plots per amendment treatment and a control (no organic amendments). Each plot area covered $40 \mathrm{~m}^{2}$ that would allow for future planting of 4 rows of corn per plot on a 0.76-m row spacing. In January 2016, soil bulk density samples were collected in 5-cm depth increments to a depth of $15-\mathrm{cm}$ from hand dug, shallow excavation pits at 1 location in each plot. The soils were oven-dried overnight at $105{ }^{\circ} \mathrm{C}$ weighed, and their bulk density values calculated accordingly to [38]. For fertility assessment, soil samples were collected at 6-8 randomly selected locations in each plot at $0-5,5-10$, and 10-15-cm depth increments using a $2.5-\mathrm{cm}$ diameter sampling probe. The samples were composited by depth and dried at $105^{\circ} \mathrm{C}$ prior to analysis. Soil samples were then analyzed for $\mathrm{pH}$, Mehlich $1 \mathrm{~K}$ (M1 K), and Mehlich 1 P (M1 P) by the Clemson University Agricultural Service Laboratory (https://www.clemson.edu/public/regulatory/ag-srvc-lab). Soil fertility concentrations by depth and plot assignment were matched with their respective soil bulk density measurements, and their final values were reported on a $\mathrm{kg} / \mathrm{ha}$ basis. This soil sampling scheme and fertility assessment was repeated in January 2017 and 2018. 
In February 2016, biochar and biochar/compost mixtures were formulated in the field, and were hand-applied and initially raked into the soil. Each plot received the equivalent of $30,000 \mathrm{~kg} / \mathrm{ha}$ of amendment (Table 2). After hand-application ceased, the amendments were then mixed to 10-cm soil depth by disking with a cultivator.

Table 2. Formulation and application of biochars and compost per treatment.

\begin{tabular}{ccc}
\hline Treatment & Biochar (kg/ha) & Compost (kg/ha) \\
\hline Control & 0 & 0 \\
\hline 100\% pine chip (PC) & 30,000 & 0 \\
\hline 100\% poultry litter (PL) & 30,000 & 0 \\
\hline PC:PL 2:1 blend & 20,000 & 10,000 \\
\hline PC: raw switchgrass (rSG) 2:1 & 20,000 & 10,000 \\
\hline rSG (compost) & 0 & 30,000
\end{tabular}

In April 2016, inorganic N-P-K starter fertilizer was applied to all plots at described rates (Table 3). During May 2016, a split application of liquid $\mathrm{N}$ was made by side dressing along corn rows. Before corn planting, all plots were initially fertilized with a granular fertilizer, containing monoammonium phosphate (MAP) and a potassium source $\left(\mathrm{K}_{2} \mathrm{O}\right)$. In all three years, corn was planted in April with the same corn variety, and planting rate was maintained (Table 3). A few weeks after planting, corn was fertilized with liquid $\mathrm{N}$ in a split application at the rate of $67 \mathrm{~kg} / \mathrm{ha}$ (total annual $\mathrm{N}$ of $147.5 \mathrm{~kg} / \mathrm{ha}$ applied). Except in 2018, MAP was not applied because soil fertility measurements showed sufficient soil $\mathrm{P}$ concentrations, so the total $\mathrm{N}$ applied was reduced to $134 \mathrm{~kg} / \mathrm{ha}$.

Table 3. Agronomic management of plots.

\begin{tabular}{cccc}
\hline Year & N-P-K Applied (kg/ha) & Corn Variety & Stand Count (Plants/ha) \\
\hline 2016 & $13.5-67-84$ (starter) & DKC64-69 & 59,406 \\
& $67-0-0$ (split) & & \\
& $67-0-0$ (split) & & 59,406 \\
\hline 2017 & $13.5-67-84$ (starter) & DKC64-69 & \\
& $67-0-0$ (split) & & 59,406 \\
& $67-0-0$ (split) & & \\
\hline 2018 & $0-56-0$ & DKC64-69 & \\
& $67-0-0$ (split) & & \\
& $67-0-0$ (split) & & \\
\hline
\end{tabular}

In 2016, 2017, and 2018, corn was planted during one operation by chiseling tilling the soil down to 40-cm using a KMC deep tiller (Kelly Manufacturing Co., Tifton, Georgia, USA) and the seeds were planted, using a Case model 1210 corn planter (Case, Inc., Grand Island, Nebraska, USA. Corn variety and stand count were kept consistent across the study period (Table 3). At the end of the season, corn grain was harvested using a mechanical harvester on the two center corn rows of each plot. Corn biomass (mass without grain weight) was quantified by physically harvesting a randomly selected $2 \mathrm{~m}$ row section of the two middle corn rows. Plant material was placed into burlap sacks and dried at $60{ }^{\circ} \mathrm{C}$, and then weighted. The biomass measured was then calculated on a dry-mass $(0 \%$ moisture content) $\mathrm{kg} / \mathrm{ha}$ basis.

The daily precipitation at the location was recorded using a rain gauge. Daily precipitation amounts were then composited for monthly and yearly totals. When precipitation results were not available, due to power outages/damage to equipment from Hurricanes Mathew (2016), and Florence (2018), the rainfall results were used from a nearby weather station at the Pee Dee SCAN site located in Darlington, South Carolina, USA (https://wcc.sc.egov.usda.gov/nwcc/site? sitenum=2037\&state=sc). 
The cumulative monthly precipitation for the critical corn growth cycle along with the dry corn yield per plot was used to determine the water use efficiency (WUE). The WUE was calculated by dividing the mean plot yields by the cumulative precipitation totals (April to August; [39]). The values of WUE were reported as $\mathrm{kg}$ grain per ha/mm precipitation [40].

\subsection{Statistics}

A 2-way ANOVA was used on the mean dry corn grain yields and dry corn biomass results, with the fixed variables being year of study and biochar treatments, and with a year $\mathrm{x}$ biochar treatment interaction. A 2-way ANOVA was also used for soil $\mathrm{pH}, \mathrm{M} 1 \mathrm{~K}$, and $\mathrm{M} 1 \mathrm{P}$ concentrations within biochar treatments, using the year of study and topsoil depths as fixed variables and their interaction was determined. The results were compared by soil depth, since plant nutrients are subject to leaching in sandy soils. All statistical analyses were determined using Sigma Stat v. 11 (SSPS Corp., Chicago, IL, USA) at a $P<0.05$ level of significance.

\section{Results}

\subsection{Designer Biochar Formulations, Application, Agronomic Management, and Precipitation Totals}

All plots received a cumulative amount of amendments at 30,000 kg/ha (Table 2). In all three years of this study, the same corn variety was planted, but the fertilizer management varied slightly (Table 3 ). Annual precipitation totals were quite variable over the three years, with totals ranging from 1116.7 to 2309.5-mm (Table 4).

Table 4. Monthly and annual precipitation totals for study period.

\begin{tabular}{cccc}
\hline & \multicolumn{3}{c}{ Precipitation (mm) } \\
\hline Month & $\mathbf{2 0 1 6}$ & $\mathbf{2 0 1 7}$ & $\mathbf{2 0 1 8}$ \\
\hline January & 57.7 & 81.3 & 72.1 \\
February & 153.9 & 48 & 35.6 \\
March & 45.7 & 50.5 & 347 \\
April & 73.1 & 104.1 & 126.4 \\
May & 108.1 & 46.9 & 129.5 \\
June & 96.1 & 170.1 & 88.4 \\
July & 213.1 & 199.6 & 122.4 \\
August & 50.8 & 94.2 & 66 \\
September & 35.1 & 101.3 & 382.8 \\
October & 322.3 & 71.9 & 469.6 \\
November & 29.46 & 17.5 & 158.2 \\
December & 154.9 & 131.3 & 311.5 \\
\hline Annual total & 1340.3 & 1116.7 & 2309.5 \\
\hline
\end{tabular}

\subsection{Corn Grain, Biomass Yields, and Water Use Efficiency}

The annual mean corn grain yields (at $0 \%$ moisture content), sorted by treatment and production year, are presented in Table 5. In 2016, corn yields from all treated plots were not significantly different than the control. It was noted, however, among the treatments in 2016, there was significant differences between only two treatments, with corn grain yields from 100\% PL being > PC:rSG 2:1 and PC:PL 2:1 blend being > PC: rSG 2:1 (Table 3). The differences in corn grain yields were $>2,300 \mathrm{~kg} / \mathrm{ha}$ between these treatments. In 2017 and 2018, however, there was no significant corn grain yield differences between all treatments. Additionally, when corn grain yields were average across years, there was no significant differences between treatment means (Table 5). 
Table 5. Comparison of annual mean corn grain yields $(n=4 ; P C=$ pine chip; $P L=$ poultry litter, $r S G=$ raw switchgrass compost).

\begin{tabular}{ccccc}
\hline \multicolumn{5}{c}{ Corn Grain Yields (dry, kg/ha) } \\
\hline Treatment & $\mathbf{2 0 1 6}{ }^{+}$ & $\mathbf{2 0 1 7}$ & $\mathbf{2 0 1 8}$ & Mean \\
\hline 100\% PC & $10,356 \mathrm{a}, \mathrm{A}$ & $9130 \mathrm{ab}, \mathrm{A}$ & $6837 \mathrm{c} \mathrm{A}$ & $8774 \mathrm{~A}$ \\
100\% PL & $10,515 \mathrm{a}, \mathrm{A}$ & $8092 \mathrm{~b}, \mathrm{~A}$ & $\mathbf{7 2 0 5} \mathrm{b}, \mathrm{A}$ & $8603 \mathrm{~A}$ \\
PC:PL 2:1 & $10,529 \mathrm{a} \mathrm{AB}$ & $8506 \mathrm{~b}, \mathrm{~A}$ & $6949 \mathrm{c}, \mathrm{A}$ & $8661 \mathrm{~A}$ \\
PC:rSG 2:1 & $8153 \mathrm{a}, \mathrm{AC}$ & $8273 \mathrm{a}, \mathrm{A}$ & $6913 \mathrm{a}, \mathrm{A}$ & $7779 \mathrm{~A}$ \\
rSG & $9164 \mathrm{a}, \mathrm{A}$ & $8232 \mathrm{ab}, \mathrm{A}$ & $6091 \mathrm{~b}, \mathrm{~A}$ & $7828 \mathrm{~A}$ \\
Control (0 biochar) & $9110 \mathrm{a}, \mathrm{A}$ & $8518 \mathrm{ab} \mathrm{A}$ & $6669 \mathrm{~b}, \mathrm{~A}$ & $8099 \mathrm{~A}$ \\
mean & $9637 \mathrm{a}$ & $8459 \mathrm{~b}$ & $6777 \mathrm{c}$ & \\
Source of variation & $P$ & & & \\
Year & $<0.001$ & & & \\
Biochar treatment & 0.085 & & & \\
Yr*Biochar trt & 0.356 & & & \\
\hline
\end{tabular}

${ }^{\dagger}$ lower case letter indicates significant differences among means between columns, while a capital letter indicates significant differences among means within a column using a 2-way ANOVA at $P<0.05$ level of significance.

When each treatment mean was compared between years of production, 5 out of 6 treatments experienced a significant corn grain yield decline, while only the PC:rSG 2:1 treatment remained similar (Table 5). Comparing the mean corn yields, when averaged across all 6 treatments, revealed that the means were significantly reduced from 9637 in 2016 to $6777 \mathrm{~kg} / \mathrm{ha}$ in 2018 (Table 5). Corn grain yield differences between 2016 versus 2018, calculated out to a reduction of $2860 \mathrm{~kg} / \mathrm{ha}$ or about $-30 \%$ change.

The effects of biochar and compost on corn biomass (without corn grain weight) were measured by year and treatment (Table 6). In 2016, there were more significant differences between treatments than noted in 2017 and 2018. Additionally, significant biomass yield declines were noted in 5 of the 6 treatments (except 100\% PC) and when averaged across all treatments by year. In fact, the differences between mean biomass yields, in 2016 and 2017, were 2344, and between 2017, and 2018 were $1265 \mathrm{~kg} / \mathrm{ha}$, respectively. Overall, the mean biomass yields across all treatments were significantly lower from 2016 to 2018 with a decline of $3709 \mathrm{~kg} / \mathrm{ha}$ (Table 6).

Table 6. Comparison of annual mean corn biomass yields (above ground biomass minus corn grain weights; $\mathrm{n}=4 ; \mathrm{PC}=$ pine chip; $\mathrm{PL}=$ poultry litter, $\mathrm{rSG}=$ raw switchgrass compost).

\begin{tabular}{ccccc}
\hline \multicolumn{5}{c}{ Corn Biomass Yields (Dry, kg/ha) } \\
\hline Biochar Treatment & $\mathbf{2 0 1 6} \mathbf{H}^{+}$ & $\mathbf{2 0 1 7}$ & $\mathbf{2 0 1 8}$ & Mean \\
\hline 100\% PC & $8365 \mathrm{a}, \mathrm{A}$ & $\mathbf{7 6 2 0} \mathrm{a}, \mathrm{A}$ & $\mathbf{7 1 0 7} \mathrm{a}, \mathrm{A}$ & $7787 \mathrm{~A}$ \\
100\% PL & $11,573 \mathrm{a}, \mathrm{B}$ & $8723 \mathrm{~b}, \mathrm{~A}$ & $\mathbf{7 2 0 2} \mathrm{b}, \mathrm{A}$ & $9166 \mathrm{BC}$ \\
PC:PL 2:1 & $11,173 \mathrm{a}, \mathrm{BC}$ & $9145 \mathrm{~b}, \mathrm{~A}$ & $6928 \mathrm{c}, \mathrm{A}$ & $9082 \mathrm{C}$ \\
PC:rSG 2:1 & $9947 \mathrm{a}, \mathrm{ABC}$ & $\mathbf{7 0 1 8} \mathrm{b}, \mathrm{A}$ & $7101 \mathrm{~b}, \mathrm{~A}$ & $8022 \mathrm{ABC}$ \\
rSG & $11,354 \mathrm{a}, \mathrm{BC}$ & $\mathbf{7 8 5 7} \mathrm{b}, \mathrm{A}$ & $6668 \mathrm{~b}, \mathrm{~A}$ & $8626 \mathrm{ABC}$ \\
Control (0 biochar) & $9430 \mathrm{a}, \mathrm{ABC}$ & $7684 \mathrm{ab}, \mathrm{A}$ & $5934 \mathrm{~b}, \mathrm{~A}$ & $7683 \mathrm{~A}$ \\
mean & $10,352 \mathrm{a}$ & $8008 \mathrm{~b}$ & $6823 \mathrm{c}$ & \\
Source of variation & $P$ & & & \\
Year & $<0.001$ & & & \\
Biochar treatment & 0.003 & & & \\
Yr*Biochar trt & 0.143 & & & \\
\hline
\end{tabular}

${ }^{+}$lower case letter indicates significant differences among means between columns, while a capital letter indicates significant differences among means within a column using a 2-way ANOVA at $P<0.05$ level of significance.

The WUE results calculated for 2016, 2017, and 2018 are presented in Table 7. The highest WUE calculated occurred in 2016, with values ranging from 15.1 to 19.4. The overall annual WUE mean for 2016 is 17.8 but has a sizable standard deviation of 1.8. In 2016, three of the treatments in 2016 (PC:rSG 
2:1, rSG and the control) had lower WUE values compared to the other three treatments. The WUE values for the treatments declined in 2017 and 2018 to $>15$, compared to the 2016 values. It was also noted that the variability of the mean also declined in 2017 and 2018.

Table 7. Water use efficiency determined for each treatment (units are kg dry corn grain per ha/mm of cumulative monthly precipitation recorded between April to August; PC = pine chip, PL = poultry litter, $\mathrm{rSG}=$ raw switchgrass compost; $\mathrm{SD}=$ standard deviation).

\begin{tabular}{cccc}
\hline Biochar trt. & $\mathbf{2 0 1 6}$ & $\mathbf{2 0 1 7}$ & $\mathbf{2 0 1 8}$ \\
\hline 100\% PC & 19.1 & 14.8 & 12.8 \\
\hline 100\% PL & 19.4 & 13.2 & 13.5 \\
\hline PC:PL 2:1 & 19.5 & 13.8 & 13 \\
\hline PC:rSG 2:1 & 15.1 & 13.5 & 13 \\
\hline rSG compost & 16.9 & 13.4 & 11.4 \\
\hline Control (0 biochar) & 16.8 & 13.9 & 12.5 \\
\hline Overall annual mean (SD) & $17.8(1.8)$ & $13.8(0.6)$ & $12.7(0.7)$ \\
\hline
\end{tabular}

\subsection{Soil Fertility}

In the mean annual $\mathrm{pH}$ values of the Goldsboro control soil, there were no significant changes between years and depth (Table 8). In contrast, the plots treated with $100 \%$ PL biochar had higher annual mean topsoil $\mathrm{pH}$ values. In these plots, the annual mean topsoil $\mathrm{pH}$ values significantly increased with time and depth $(P<0.001$ and 0.014 , respectively, Table 8$)$. Mean annual topsoil $\mathrm{pH}$ values after treatment with $100 \%$ PC biochar, the two blends, and the raw switchgrass compost were mixed. While 4 of 6 treatments exhibited significant impacts of time on soil $\mathrm{pH}$, in contrast, only 1 of 6 treatments showed a significant depth impact (Table 9).

The Goldsboro control soil, without the biochar addition, had no significant time or depth effect (Table 9). Meanwhile, amending the Goldsboro soil with 100\% PL biochar significantly raised the annual mean topsoil ( 0 to $15 \mathrm{~cm}$ ) M1 P concentration. There is a very significant time and depth impact of $100 \%$ PL biochar on soil M1 P concentrations $(P<0.001$; Table 9$)$. In fact, M1 P is stratified in the Goldsboro soils treated with 100\% PL biochar because the two topsoil depths had the highest M1 P concentrations, while the 10-15 cm depth soil sample had the lowest M1 P concentration (Table 9). Blending the PL biochar with PC biochar in a 2:1 (w/w) ratio resulted in a decrease in annual mean topsoil M1 P concentrations. There is a very significant impact of time and depth and interaction effect with this treatment $(P<0.001)$. The addition of $100 \%$ PC biochar also resulted in small but significant increases in annual mean topsoil M1 P concentrations. In fact, the $100 \%$ PC biochar amendments caused both a significant year and depth impact on M1 P concentrations. Finally, the treatment of the Goldsboro soil with PC:rSG 2:1 (w/w) blend and the rSG compost resulted in no effect on soil M1 P concentrations.

The control soils had annual mean topsoil M1 K concentrations that did not vary as a function of time $(P=0.076$; Table 10$)$. However, there was a significant depth and year ${ }^{*}$ depth interaction $(P<0.001)$, suggesting stratification with higher mean $\mathrm{K}$ concentrations in the surface $0-5 \mathrm{~cm}$ soil depth. Adding 100\% PL biochar, and the two blends significantly increased the soil M1 K concentrations (Table 10). Changes in topsoil M1 K concentrations in the 100\% PL treatment is supported by the very significant year effect $(P<0.001$; Table 10). 
Table 8. Mean $\mathrm{pH}$ by soil depth per year of study (SOV = source of variation, $P$ value in brackets).

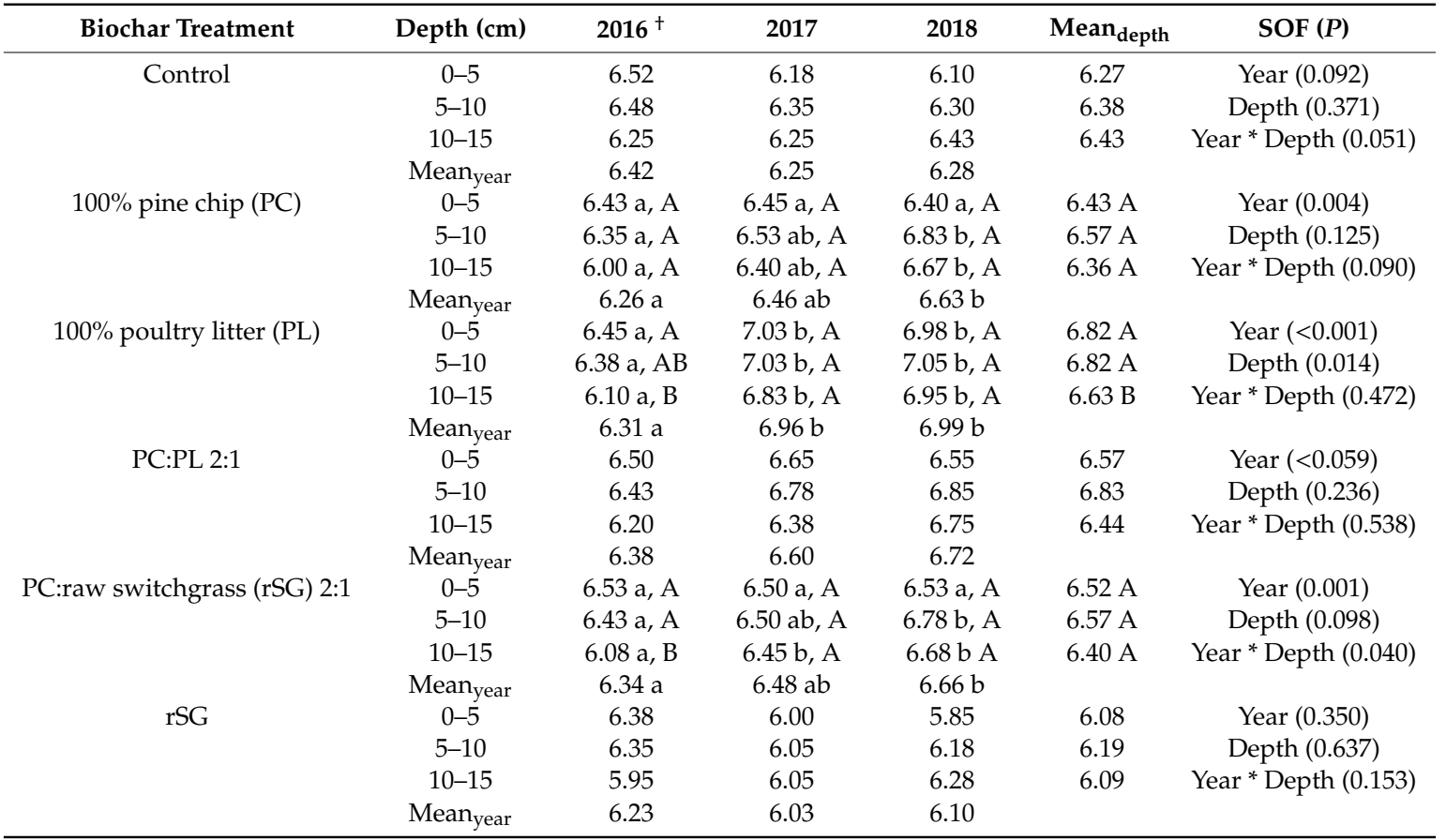

${ }^{\dagger}$ lower case letter indicates significant differences among means between columns, while a capital letter indicates significant differences among means within a column using a 2-way ANOVA at $P<0.05$ level of significance.

Table 9. Mean Mehlich $1 \mathrm{P}$ contents (kg/ha) by soil depth per year of study (SOV = source of variation, $P$ value in brackets).

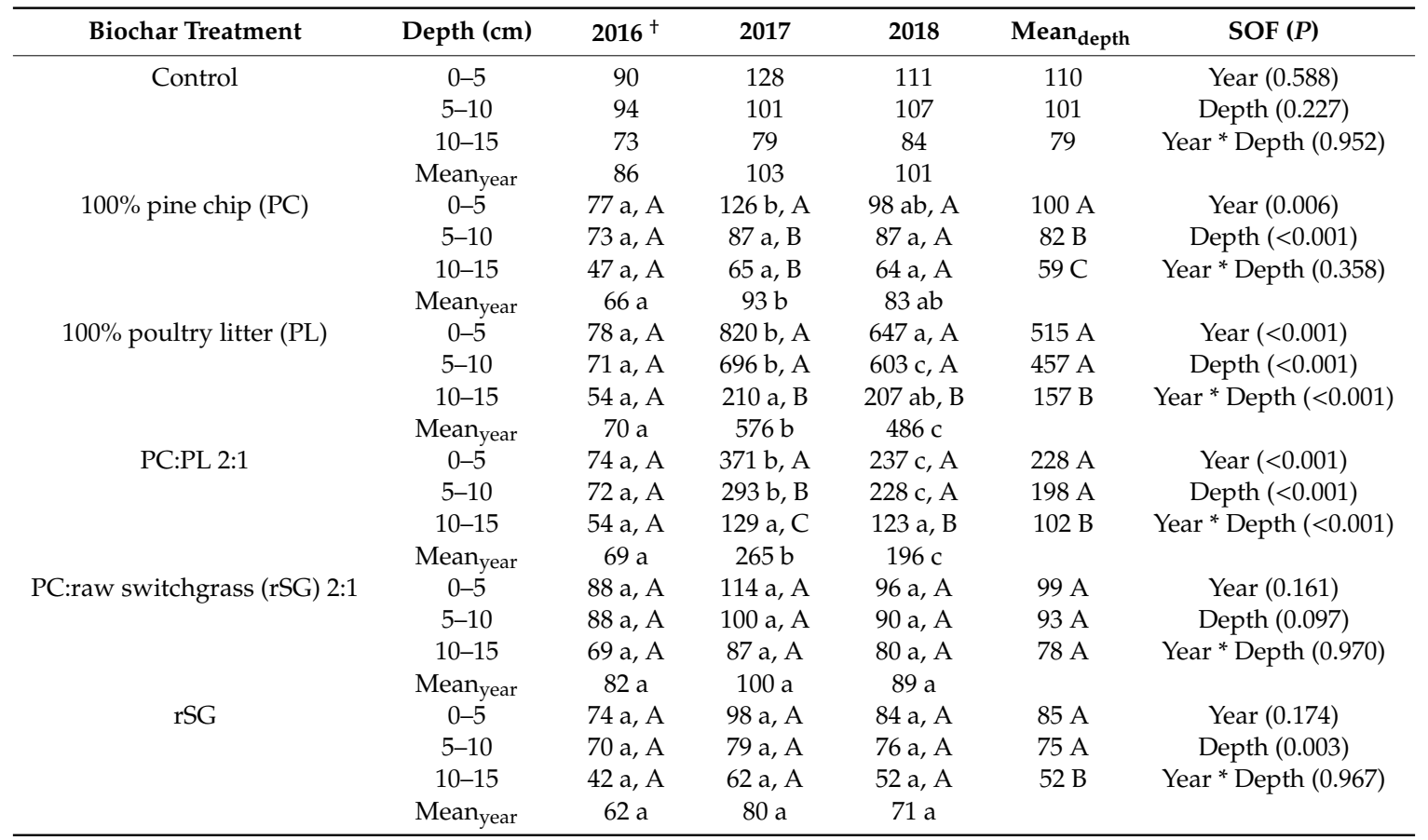

${ }^{\dagger}$ lower case letter indicates significant differences among means between columns, while a capital letter indicates significant differences among means within a column using a 2 -way ANOVA at $P<0.05$ level of significance. 
Table 10. Mean Mehlich $1 \mathrm{~K}$ (kg/ha) contents by soil depth per year of study (SOV = source of variation, $P$ value in brackets).

\begin{tabular}{|c|c|c|c|c|c|c|}
\hline Biochar treatment & Depth (cm) & $2016^{+}$ & 2017 & 2018 & Mean $_{\text {depth }}$ & SOF $(P)$ \\
\hline \multirow[t]{4}{*}{ Control } & $0-5$ & $122 \mathrm{a}, \mathrm{A}$ & $207 \mathrm{~b}, \mathrm{~A}$ & $208 \mathrm{~b}, \mathrm{~A}$ & $178 \mathrm{~A}$ & Year (0.076) \\
\hline & $5-10$ & $146 \mathrm{a}, \mathrm{A}$ & $117 \mathrm{a}, \mathrm{B}$ & $145 \mathrm{a}, \mathrm{B}$ & $136 \mathrm{~B}$ & Depth $(<0.001)$ \\
\hline & 10-15 & 146 a, A & 86 b, B & $118 \mathrm{ab}, \mathrm{B}$ & $117 \mathrm{~B}$ & Year * Depth $(<0.001)$ \\
\hline & Mean $_{\text {year }}$ & $138 \mathrm{a}$ & $136 \mathrm{a}$ & 157 a & & \\
\hline \multirow[t]{4}{*}{$100 \%$ pine chip $(\mathrm{PC})$} & $0-5$ & $142 \mathrm{a}, \mathrm{A}$ & $221 \mathrm{~b}, \mathrm{~A}$ & $195 \mathrm{~b}, \mathrm{~A}$ & $186 \mathrm{~A}$ & Year (0.989) \\
\hline & $5-10$ & $160 \mathrm{a}, \mathrm{A}$ & $142 \mathrm{a}, \mathrm{B}$ & $153 \mathrm{a}, \mathrm{B}$ & $152 \mathrm{~B}$ & Depth $(<0.001)$ \\
\hline & 10-15 & $163 \mathrm{a}, \mathrm{A}$ & $105 \mathrm{~b}, \mathrm{C}$ & $121 \mathrm{ab}, \mathrm{B}$ & $130 \mathrm{C}$ & Year * Depth $(<0.001)$ \\
\hline & Mean $_{\text {year }}$ & $155 \mathrm{a}$ & $156 \mathrm{a}$ & $156 \mathrm{a}$ & & \\
\hline \multirow[t]{4}{*}{$100 \%$ poultry litter $(\mathrm{PL})$} & $0-5$ & $137 \mathrm{a}, \mathrm{A}$ & $494 \mathrm{~b}, \mathrm{~A}$ & 329 c, A & $320 \mathrm{~A}$ & Year $(<0.001)$ \\
\hline & $5-10$ & $161 \mathrm{a}, \mathrm{A}$ & $524 \mathrm{~b}, \mathrm{~A}$ & $310 \mathrm{c}, \mathrm{A}$ & $332 \mathrm{~A}$ & Depth (0.611) \\
\hline & 10-15 & $161 \mathrm{a}, \mathrm{A}$ & $462 \mathrm{~b}, \mathrm{~A}$ & $268 \mathrm{a}, \mathrm{A}$ & $297 \mathrm{~A}$ & Year * Depth (0.856) \\
\hline & Mean $_{\text {year }}$ & $153 \mathrm{a}$ & $494 \mathrm{~b}$ & $303 c$ & & \\
\hline \multirow[t]{4}{*}{ PC:PL 2:1 } & $0-5$ & $125 \mathrm{a}, \mathrm{A}$ & $331 \mathrm{~b}, \mathrm{~A}$ & $250 \mathrm{ab}, \mathrm{A}$ & $235 \mathrm{~A}$ & Year $(<0.001)$ \\
\hline & $5-10$ & $137 \mathrm{a}, \mathrm{A}$ & $268 \mathrm{a}, \mathrm{A}$ & $193 \mathrm{a}, \mathrm{A}$ & $199 \mathrm{~A}$ & Depth (0.662) \\
\hline & $10-15$ & $133 \mathrm{a}, \mathrm{A}$ & $339 \mathrm{~b}, \mathrm{~A}$ & $177 \mathrm{~b}, \mathrm{~A}$ & $216 \mathrm{~A}$ & Year * Depth $(0.770)$ \\
\hline & Mean $_{\text {year }}$ & $132 \mathrm{a}$ & $312 \mathrm{~b}$ & 207 b & & \\
\hline \multirow[t]{4}{*}{ PC:raw switchgrass (rSG) 2:1 } & $0-5$ & $118 \mathrm{a}, \mathrm{A}$ & $223 \mathrm{~b}, \mathrm{~A}$ & $203 \mathrm{~b}, \mathrm{~A}$ & $181 \mathrm{~A}$ & Year (0.027) \\
\hline & $5-10$ & $143 \mathrm{a}, \mathrm{AB}$ & $130 \mathrm{a}, \mathrm{B}$ & $143 \mathrm{a}, \mathrm{B}$ & $139 \mathrm{~B}$ & Depth $(<0.001)$ \\
\hline & 10-15 & $148 \mathrm{a}, \mathrm{B}$ & 104 b, C & $113 \mathrm{~b}, \mathrm{C}$ & $122 \mathrm{C}$ & Year ${ }^{*}$ Depth $(<0.001)$ \\
\hline & Mean $_{\text {year }}$ & 136 a & $152 \mathrm{~b}$ & $153 \mathrm{~b}$ & & \\
\hline \multirow[t]{4}{*}{ rSG } & $0-5$ & 149 a, A & $201 \mathrm{a}, \mathrm{A}$ & $184 \mathrm{a}, \mathrm{A}$ & $178 \mathrm{~A}$ & Year $(0.391)$ \\
\hline & $5-10$ & $164 \mathrm{a}, \mathrm{A}$ & $127 \mathrm{a}, \mathrm{A}$ & $128 \mathrm{a}, \mathrm{A}$ & $140 \mathrm{~A}$ & Depth $(0.643)$ \\
\hline & 10-15 & $154 \mathrm{a}, \mathrm{A}$ & $301 \mathrm{a}, \mathrm{A}$ & $106 a, a$ & $187 \mathrm{~A}$ & Year * Depth $(0.491)$ \\
\hline & Mean $_{\text {year }}$ & 156 a & $210 \mathrm{a}$ & 139 a & & \\
\hline
\end{tabular}

${ }^{\dagger}$ lower case letter indicates significant differences among means between columns, while a capital letter indicates significant differences among means within a column using a 2 -way ANOVA at $P<0.05$ level of significance.

Likewise, the PC:PL 2:1 blend also increased M1 K extractable concentrations to be approximately 2-fold greater than the control. After some time, however, there was a significant reduction in M1 $\mathrm{K}(P<0.001$; Table 10). There was no depth effect in this treatment. Additions of PC:rSG 2:1 also increased M1 K concentrations but only in the top $0-5 \mathrm{~cm}$ soil depth. This stratification contributed to the very significant depth effect and year ${ }^{*}$ depth interaction $(P<0.001$; Table 10$)$. Finally, rSG additions did not significantly impact soil M1 K concentrations, which is related to its low $\mathrm{K}$ concentration in the compost $(0.29 \%$; Table 1$)$ and low amount delivered to soil $(87 \mathrm{~kg} / \mathrm{ha} ; 0.0029 * 30,000 \mathrm{~kg} / \mathrm{ha}$; Tables 1 and 2).

\section{Discussion}

Pine chip biochar was used in this study to bolster the Goldsboro Ap horizon SOC content ( $0.91 \%$ SOC in $0-15 \mathrm{~cm}$ deep, data not presented). The 100\% PL biochar was selected to bolster the Goldsboro's soils macro (i.e., $\mathrm{P}$ and $\mathrm{K}$ ), and micro (i.e, $\mathrm{Cu}$ and $\mathrm{Zn}$ ) nutrient concentrations. Because PC biochar inherently contains lower quantities of plant nutrients relative to manure-based biochar [14,21], it was blended in a 2:1 (w/w) ratio with nutrient enriched PL biochar (Table 1). This blending of biochars expands the soil fertility benefits by increasing both SOC and plant nutrient concentrations. Additionally, a switchgrass compost was included in the treatments because of anticipated improvement in biochar nutrient transformation processes [33] and soil moisture retention [32,41].

In this study, the biochar applications rates are equivalent to a rate of $30,000 \mathrm{~kg} / \mathrm{ha}$ (Table 2). This application rate is within the range $(10,000$ to $50,000 \mathrm{~kg} / \mathrm{ha})$ used in other fields [41-43], or in our prior laboratory experiments, involving biochar on sandy coastal plain soils [2,6].

For corn grain yields, the addition of designer biochar to the Goldsboro soil had little influence (Table 5). Some variations between treatments in 2016 did occur, although there was some minor impacts of amendments between the individual treatments. It was noted that, in 2016, corn grain yields 
from the 100\% PL treatment were > PC:rSG 2:1 and the PC:PL 2:1 blend was > PC: rSG 2:1 (Table 5). In term of differences, the corn grain yields were $>2300 \mathrm{~kg} / \mathrm{ha}$ between these two treatments.

When each treatment mean was compared between years of production, 5 out of 6 treatments experienced a significant corn grain yield decline, while only the PC:rSG 2:1 treatment remained similar. The decline in annual yields was evident by comparing the mean corn yield when averaged across all 6 treatments, which showed that mean corn yields were significantly reduced from 9637 in 2016 to $6777 \mathrm{~kg} / \mathrm{ha}$ in 2018 (Table 5). Corn grain yield differences between 2016 versus 2018 calculated a reduction of $2860 \mathrm{~kg} / \mathrm{ha}$ or about $-30 \%$ change.

The literature has reported mixed results, concerning the biochars' impact on corn grain yields. In a three-year mesocosm experiment, Borchard et al. [19] reported that a wood-based biochar, applied to a sandy Fluvisol and a silty Luvisol, failed to improve corn yields. In a larger field scale study conducted at several United States Department of Agriculture-Agricultural Research Service locations across the USA, Laird et al. [20] reported that a hardwood biochar applied to soils had no significant impact on corn grain yield increases at 5 of the 6 locations. Additionally, Güereña et al. [44] reported that corn yields did not change when grown in two New York soils after biochar additions, even when applied at 30,000 $\mathrm{kg} / \mathrm{ha}$. It was speculated in this study that the maize-based biochar did not work in these soils, because there were no fertility constraints, and that the site was in a temperate climate with adequate precipitation totals. In a more recent biochar field study, Lamb et al. [44] also reported no positive impact of a hardwood-derived biochar on corn yields grown in a sandy Ultisol in Georgia.

In contrast, there are numerous biochar studies, conducted under tropical conditions, that have reported maize grain yield increases from field trials, using different feedstocks $[45,46]$. In one study, Cornelissen et al. [47] reported a positive corn yield increase in a sandy, African Ultisol treated with biochar produced from corn cob/softwood. Additionally, Agegnehu et al. [33] reported a significant corn yield improvement in tropical Ferralsol treated with biochar produced from waste willow wood. These studies reported that biochar has a positive interaction with tropical soils to improve corn grain yields, which was further corroborated in a global-scale meta-analysis, that biochar boosts crop yields in tropical but not temperate zones [17].

The contrasting effects of biochar improving crop yields in tropical soils but having mixed effects at raising yields in temperate soils is a concern. Biochars in tropical soils may be more effective at improving soil fertility conditions by raising low soil $\mathrm{pH}$ levels, sequestering phytotoxic aluminum concentrations, adding critical plant nutrients, or by enhancing nutrient turnover properties through stimulating soil microbial populations. Furthermore, biochars' positive crop yield effects, in tropical soils, may be enhanced by mixing with compost [33,34]. On the other hand, biochars' inconsistent performance at increasing crop yields in temperate regions may be related to the wrong biochar applied to an incorrect soil, the soil did not need biochar addition, or that the background soil fertility properties were of sufficient quality to mask biochar responses on soil properties. The ability to explain why crop yields vary with biochar applications under different climate condition or soil properties is problematic. It may be that strategies to improve biochars' inconsistent performance in soils, under temperate climates, will require additional field investigations that specifically identify which soil properties were modified, and how strongly do these changes induce a positive crop yield increase. Otherwise, if biochars expenses are not recouped through associate higher crop grain or biomass yields, then their future use in agricultural as a soil amendment may be limited.

In our study, the effects of biochar and compost on the mean corn biomass (without corn grain weight) showed some significant differences in the first year of study, but were not apparent by the second and third year (Table 6). Similar to the corn grain yields, biomass yields also experienced a significant decline in five of the six treatments (except 100\% PC), when averaged across all treatments by year. This represents a $36 \%$ decline in mean corn biomass yields, when averaged across all treatments in just three years. This result is similar to corn biomass reductions (i.e., 36\%) as reported [48].

Large variations in annual rainfed corn grain yields in the Southeastern USA Coastal Plain region are not uncommon. Heckman and Kamprath [49] observed large annual variations of between 20 to 
$50 \%$ in corn grain yields in a three-year corn production experiment when grown in a NC Dothan loamy sand. Davis et al. [50] also reported that over 11 years, there were large annual mean variations of between 25 to $50 \%$ in a corn production experiment grown in a Tifton loamy sand in GA. They attributed the large variation to differences in monthly rainfall. Similar to this study, a decline in corn grain yields may be due to irregular precipitation timing during critical periods of corn pollination and seed filling stages (April to August) of production (Table 4). Although there were near, or above annual precipitation totals (i.e., 1200-mm; [51]), the irregular monthly precipitation totals in May and August 2017, and June and August 2018, probably impacted corn pollination and eventual seed filling. The decline in WUE, calculated in 2017 and 2018, suggests that the corn crop in all treatments was under moisture stress relative to 2016. While the amount of annual precipitation is important, a more vital component is the timing of that precipitation event during critical corn growth cycles to minimize water limited corn yields [52].

Three important soil fertility characteristics were evaluated in this study including, soil pH, M1 $\mathrm{P}$, and M1 K concentrations. Soils were also collected annually in 5-cm topsoil increments because the lack of mechanical mixing during conservation tillage operations was speculated to cause vertical stratification in nutrient concentrations. Additionally, $\mathrm{K}$ is reported to readily leach through sandy coastal plain soils after treatment with PL biochar [53]. Sampling, using this procedure, would allow for the assessment of nutrient vertical stratification and for salt leaching, which may influence soil $\mathrm{pH}$ or reductions in nutrient concentrations biding in the topsoil.

Th $\mathrm{pH}$ range for soils in the control and with biochar treatment (except soil treated with $100 \%$ PL biochar) are well within the soil pH realm considered optimum (e.g., $\mathrm{pH} 5.5$ to 6.5) for nutrient availability in Coastal Plain soils [54]. In soil treated with 100\% PL biochar, the increase in $\mathrm{pH}$ is not unexpected because $100 \%$ PL biochars typically have calcareous $\mathrm{pH}$ values, due to high concentrations of residual salts in their ash $[6,11]$ and higher ash contents (Table 1). This condition is also related to the Goldsboro soil having a limited ability to buffer salts contained with the $100 \%$ PL biochar [6]. With the use of $100 \%$ PL biochar on sandy soils, it is important that resultant soil $\mathrm{pH}$ values do not exceed seven, since $\mathrm{Fe}, \mathrm{Mg}$, $\mathrm{Zn}$, and other micronutrients become less available for plant uptake [54,55].

Three of the six treatments had a significant impact of time on soil pH (Table 8). This condition is probably related to salts leaching out of the biochar as a function of time, and re-establishing the equilibrium with cations associated on clays and in the soil organic carbon pool. After displacement, the salts would promote alkaline conditions because of the higher dissolved $\mathrm{Ca}$ and $\mathrm{Mg}$ concentrations. Ranking the 2018 mean annual soil $\mathrm{pH}$ values grouped by topsoil depth were $100 \%$ PL > PC:PL 2:1 > PC:rSG 2:1 $\geq 100 \%$ PC > control > rSG treatment. This corroborates that the calcareous $100 \%$ PL and PC:PL 2:1 biochars were more effective at raising $\mathrm{pH}$ values in the Goldsboro soil than the other treatments.

Biochars, used as soil amendments, can contribute plant nutrients, such as $\mathrm{P}$ and $\mathrm{K}$ to bolster the overall soil fertility status [14]. As shown in Table 9, biochars had different capabilities of supplying $\mathrm{P}$ to soil. Expressing the relative effectiveness of these biochars and compost to supply M1 P to the Goldboro soil are: 100\% PL > PC:PL 2:1 blend > 100\% PC > PC:rSG = rSG compost.

According to the recommended levels for agronomic crop growth in Coastal Plain soils, M1 P concentrations presented in Table 9 show that they rank in the high (67 to $112 \mathrm{~kg} / \mathrm{ha}$ ) to very high (+112 kg/ha; [54]) range. Obviously, adding 30,000 kg/ha of 100\% PL biochar to the Goldsboro soil grossly increased the M1 P concentrations to be much greater than the highest M1 P level recommended for Coastal Plain sandy soils. The depth stratification of M1 P to about $10 \mathrm{~cm}$ is reflective of the biochar being disked incorporated after application.

Potassium is an important plant nutrient because it is involved in many enzymatic functions, regulates electrochemical balances between plant organelles, and contributes to osmotic potential reactions of cells and tissues [56]. Because $\mathrm{K}$ is involved in many plant physiological functions, for example, corn can have a high $\mathrm{K}$ nutrition requirement ranging from 3.2 to $28 \mathrm{~kg} / \mathrm{ha} / \mathrm{d}$ [57]. The exact $\mathrm{K}$ nutrition requirement varies with geographic locations due to differences in planting rate, 
soil water availability, and production stage of growth [57]. Typically, large fertilizer $\mathrm{K}_{2} \mathrm{O}$ rates are applied annually for corn production. For example, $\mathrm{K}_{2} \mathrm{O}$ application rates ranged from 167 to $224 \mathrm{~kg} / \mathrm{ha}$ in a field corn experiment in a SC sandy Coastal Plain soil [58]. However, the actual amount of $\mathrm{K}_{2} \mathrm{O}$ applied each year depends on antecedent M1 K soil tests values. For example, soil test M1 potassium concentrations ranges for corn production in SC are low ( $<80 \mathrm{~kg} / \mathrm{ha}$ ); medium (80 to $175 \mathrm{~kg} / \mathrm{ha}$ ); sufficient (176 to $204 \mathrm{~kg} / \mathrm{ha}$ ); high (205 to $263 \mathrm{~kg} / \mathrm{ha}$ ) and excessive (>263 kg/ha; [58]).

Here, the M1 K levels were measured in the Goldsboro control soil rank in the medium soil test category, thereby suggesting a need to maintain inorganic $\mathrm{K}_{2} \mathrm{O}$ fertilizer additions. For the $\mathrm{M} 1 \mathrm{~K}$ concentrations, it is interesting that there was no depth effect in the Goldsboro soil treated with 100\% PL, PC:PL 2:1 biochar, or rSG compost (Table 10). This may be explained by a better degree of physical mixing in these plots. In contrast, soil in plots treated with 100\% PC biochar and PC:rSG 2:1 had significant depth effects with greater concentrations measured at the 0 to $5-\mathrm{cm}$ depth. The may be linked to a relatively poorer degree of physical mixing or to the lack of $\mathrm{K}$ released from the cellulosic material. Overall, the application of 30,000 kg/ha of 100\% PL biochar increased M1 K concentrations, so that it was in the excessive soil test range.

\section{Conclusions}

Customizing biochar properties to match specific soil deficiencies was suggested as a more effective paradigm for biochar usage. The use of designer biochars was reported to more effectively increase corn grain yields or biomass production, compared to a non-specific biochar. Here, we report that designer biochars were able to improve important fertility properties (e.g., $\mathrm{pH}, \mathrm{M} 1 \mathrm{P}$, and $\mathrm{K}$ ) in the sandy Goldsboro soil. In spite of the noted soil fertility improvements, however, corn grain and biomass yields were not significantly raised. In comparison, when averaged by year, annual mean grain yield and biomass production both declined by about $30 \%$. The declines were probably due to weather fluctuations during critical corn growth stages (i.e., fertilization, seed filling). The lack of significant improvement in corn yields in this study, corroborates the results from other biochar field research projects, conducted in temperate regions. In conclusion, despite the Goldsboro soil being extensively weathered, it still possessed sufficient soil fertility traits that, with good agronomic practices and timely rainfall, can produce satisfactory corn yields.

Author Contributions: All authors contributed to this research project. Individual contributions to the following categories are as follows: Conceptualization, J.M.N., G.C.S., and T.F.D.; methodology, J.M.N., D.W.W., G.C.S., T.D.D., and K.C.S.; formal aanalysis, J.M.N. and K.C.S.; writing-original draft preparation, J.M.N.; writing-review and editing, J.M.N., K.C.S., and D.W.W.; visualization, J.M.N.

Funding: This research was funded by Agricultural Research Service, grant number 6082-12630-001-00D.

Acknowledgments: Gratitude is expressed to the technical staff for their work and diligence with sample collection, field preparation, and analyses. This work was made possible through the United States Department of Agriculture-Agricultural Research Service (USDA-ARS) National Program 212 (Soil and Air) Project number 6082-12630-001-00D. It has been subject to peer review by USDA-ARS scientists and approved for journal submission. Approval does not signify that the contents of this paper reflect the views of the USDA-ARS nor does mention of trade names or commercial products constitute endorsement or recommendation for their use. USDA is an equal opportunity provider and employer.

Conflicts of Interest: There are no conflict of interests.

\section{References}

1. Busscher, W.J.; Novak, J.M.; Evans, D.E.; Watts, D.W.; Niandou, M.A.S.; Ahmedna, M. Influence of Pecan Biochar on Physical Properties of a Norfolk Loamy Sand. Soil Sci. 2010, 175, 10-14. [CrossRef]

2. Novak, J.M.; Busscher, W.J.; Watts, D.W.; Amonette, J.E.; Ippolito, J.A.; Lima, I.M.; Gaskin, J.; Das, K.C.; Steiner, C.; Ahmedna, M.; et al. Biochars Impact on Soil-Moisture Storage in an Ultisol and Two Aridisols. Soil Sci. 2012, 177, 310-320. [CrossRef]

3. Mukherjee, A.; Lal, R. Biochar Impacts on Soil Physical Properties and Greenhouse Gas Emissions. Agronomy 2013, 3, 313-339. [CrossRef] 
4. Blanco-Canqui, H. Biochar and Soil Physical Properties. Soil Sci. Soc. J. 2017, 84, 687. [CrossRef]

5. Liang, B.; Lehmann, J.; Solomon, D.; Kinyangi, J.; Grossman, J.M.; O’Neill, B.; Skjemstad, J.O.; Thies, J.; Luizão, F.J.; Petersen, J.; et al. Black Carbon Increases Cation Exchange Capacity in Soils. Soil Sci. Soc. J. 2006, 70, 1719-1730. [CrossRef]

6. Novak, J.M.; Lima, I.; Xing, B.; Gaskin, J.W.; Steiner, C.; Das, K.C.; Ahmedna, M.; Rehrah, D.; Watts, D.W.; Busscher, W.J.; et al. Characterization of designer biochar produced at different temperatures and their effects on a loamy sand. Ann. Env. Sci. 2009, 3, 195-206.

7. Ippolito, J.; Ducey, T.; Cantrell, K.; Novak, J.; Lentz, R. Designer, acidic biochar influences calcareous soil characteristics. Chemosphere 2016, 142, 184-191. [CrossRef] [PubMed]

8. Domingues, R.R.; Trugilho, P.F.; Silva, C.A.; De Melo, I.C.N.A.; Melo, L.C.A.; Magriotis, Z.M.; Sánchez-Monedero, M.A. Properties of biochar derived from wood and high-nutrient biomasses with the aim of agronomic and environmental benefits. PLOS ONE 2017, 12, e0176884. [CrossRef] [PubMed]

9. Kleber, M.; Hockaday, W.; Nico, P.S. Characteristics of biochar: macro-molecular properties. In Biochar for Environmental Management, 2nd ed.; Lehmann, J., Joseph, S., Eds.; Earthscan: Routledge, NY, USA, 2015; pp. 111-138.

10. Brassard, P.; Godbout, S.; Raghavan, V. Soil biochar amendment as a climate change mitigation tool: Key parameters and mechanisms involved. J. Environ. Manag. 2016, 181, 484-497. [CrossRef] [PubMed]

11. Novak, J.M.; Johnson, M.G. Elemental and spectroscopic characterization of low-temperature $\left(350{ }^{\circ} \mathrm{C}\right)$ lignocellulosic- and manure-based designer biochars and their use as soil amendments. In Biochar and Biomass and Waste; Ok, Y.S., Tsang, D.C., Bolan, N., Novak, J.M., Eds.; Elsevier Publisher: Cambridge, MA, USA, 2018; pp. 21-36.

12. Cantrell, K.B.; Hunt, P.G.; Uchimiya, M.; Novak, J.M.; Ro, K.S. Impact of pyrolysis temperature and manure source on physiocochemical characteristics of biochar. Bioresour. Technol. 2012, 107, 419-428. [CrossRef] [PubMed]

13. Biederman, L.A.; Harpole, W.A. Biochar and its effects on plant productivity and nutrient cycling: a meta-analysis. GCB Bioenergy 2013, 5, 202-214. [CrossRef]

14. Ippolito, J.A.; Spokas, K.A.; Novak, J.M.; Lentz, R.D.; Cantrell, K.B. Biochar elemental composition and factors influencing nutrient retention. In Biochar for Environmental Management, 2nd ed.; Lehmann, J., Joseph, S., Eds.; Earthscan: Routledge, NY, USA, 2015; pp. 139-163.

15. Jeffery, S.; Verheijen, F.; Van Der Velde, M.; Bastos, A.C. A quantitative review of the effects of biochar application to soils on crop productivity using meta-analysis. Agric. Ecosyst. 2011, 144, 175-187. [CrossRef]

16. Crane-Droesch, A.; Torn, M.S.; Abiven, S.; Jeffery, S. Heterogeneous global crop yield response to biochar: a meta-regression analysis. Environ. Lett. 2013, 8, 044049. [CrossRef]

17. Jeffery, S.; Abalos, D.; Prodana, M.; Bastos, A.; Van Groenigen, J.W.; Hungate, B.; Verheijen, F. Biochar boosts tropical but not temperate crop yields. Environ. Lett. 2017, 12, 53001. [CrossRef]

18. Spokas, K.; Cantrell, K.B.; Novak, J.M.; Archer, D.W.; Ippolito, J.A.; Collins, H.P.; Boateng, A.A.; Lima, I.M.; Lamb, M.C.; McAloon, A.J.; et al. Biochar: A Synthesis of Its Agronomic Impact beyond Carbon Sequestration. J. Qual. 2012, 41, 973. [CrossRef] [PubMed]

19. Borchard, N.; Siemens, J.; Ladd, B.; Möller, A.; Amelung, W. Application of biochars to sandy and silty soil failed to increase maize yield under common agricultural practice. Soil N.a. 2014, 144, 184-194. [CrossRef]

20. Laird, D.; Novak, J.; Collins, H.; Ippolito, J.; Karlen, D.; Lentz, R.; Sistani, K.; Spokas, K.; Van Pelt, R. Multi-year and multi-location soil quality and crop biomass yield responses to hardwood fast pyrolysis biochar. Geoderma 2017, 289, 46-53. [CrossRef]

21. Novak, J.M.; Cantrell, K.B.; Watts, D.W. Compositional and thermal evaluation of lignocellulosic and poultry litter chars via high and low temperature pyrolysis. Bioenerg. Res. 2013, 6, 114-130. [CrossRef]

22. Zhang, J.; Liu, J.; Liu, R. Effects of pyrolysis temperature and heating time on biochar obtained from the pyrolysis of straw and lignosulfonate. Bioresour. Technol. 2015, 176, 288-291. [CrossRef]

23. Suliman, W.; Harsh, J.B.; Abu-Lail, N.I.; Fortuna, A.-M.; Dallmeyer, I.; Garcia-Perez, M. Influence of feedstock source and pyrolysis temperature on biochar bulk and surface properties. Biomass and Bioenergy 2016, 84, 37-48. [CrossRef]

24. Anderson, N.M.; Bergman, R.D.; Page-Dumroese, D.S. A supply chain approach to biochar systems. In Biochar: A Regional Supply Chain Approach in View of Climate Change Mitigation; Bruckman, V., Varol, E.A., Uzan, B., Liu, J., Eds.; Cambridge University Press: Cambridge, UK, 2017; pp. $24-45$. 
25. Novak, J.M.; Busscher, W.J. Selection and use of designer biochars to improve characteristics of southeastern usa coastal plain degraded soils. In Advanced Biofuels and Bioproducts; Springer Nature: New York, NY, USA, 2012; pp. 69-96.

26. Novak, J.M.; Cantrell, K.B.; Watts, D.W.; Busscher, W.J.; Johnson, M.G. Designing relevant biochar as soil amendments using lingo-cellulosic-based and manure-based feedstocks. J. Soil Sediment. 2014, 14, 330-343. [CrossRef]

27. Atkinson, C.J.; Fitzgerald, J.D.; Hipps, N.A. Potential mechanisms for achieving agricultural benefits from biochar application to temperate soils: A review. Plant Soil 2010, 337, 1-18. [CrossRef]

28. Joseph, S.; Van Zwieten, L.V.; Cjia, C.; Kimber, S.; Munroe, P.; Lin, Y.; Marjo, C.; Hook, J.; Thomas, T.; Nielsen, S.; et al. Designing specific biochars to address soil constraints: A developing industry. In Biochar and Soil Biota; Ladygina, N., Rineau, F., Eds.; CRC Press: Boca Raton, FL, USA, 2010; pp. 165-201.

29. Mandal, S.; Sarkar, B.; Bolan, N.; Novak, J.; Ok, Y.S.; Van Zwieten, L.; Singh, B.P.; Kirkham, M.B.; Choppala, G.; Spokas, K.; et al. Designing advanced biochar products for maximizing greenhouse gas mitigation potential. Crit. Rev. Environ. Sci. Technol. 2016, 46, 1-35. [CrossRef]

30. Sigua, G.; Novak, J.; Watts, D.; Johnson, M.; Spokas, K. Efficacies of designer biochars in improving biomass and nutrient uptake of winter wheat grown in a hard setting subsoil layer. Chemosphere 2016, 142, 176-183. [CrossRef] [PubMed]

31. Novak, J.M.; Busscher, W.J.; Laird, D.L.; Ahmedna, M.; Watts, D.W.; Niandou, M.A.S. Impact of Biochar Amendment on Fertility of a Southeastern Coastal Plain Soil. Soil Sci. 2009, 174, 105-112. [CrossRef]

32. Novak, J.M.; Watts, D.W. Augmenting soil water storage using uncharred switchgrass and pyrolyzed biochars. Soil Use Manag. 2013, 29, 98-104. [CrossRef]

33. Agegnehu, G.; Bass, A.M.; Nelson, P.N.; Bird, M.I. Benefits of biochar, compost and biochar-compost for soil quality, maize yield and greenhouse gas emissions in a tropical agricultural soil. Sci. Total. Environ. 2016, 543, 295-306. [CrossRef] [PubMed]

34. Lashari, M.S.; Liu, Y.; Li, L.; Pan, W.; Fu, J.; Pan, G.; Zheng, J.; Zheng, J.; Zhang, X.; Yu, X. Effects of amendments of biochar-manure compost in conjuction with pyroligneous solution on soil quality and wheat yield of a salt-stressed cropland from Central China Great Plain. Field Crops Res. 2013, 144, 113-118. [CrossRef]

35. Daniels, R.B.; Buol, S.W.; Kleiss, H.J.; Ditzler, C.A. Soil Systems in North Carolina, Technical Bulletin 314; North Carolina State University: Raleigh, NC, USA, 1999.

36. A Ippolito, J.; Berry, C.M.; Strawn, D.G.; Novak, J.M.; Levine, J.; Harley, A. Biochars Reduce Mine Land Soil Bioavailable Metals. J. Qual. 2017, 46, 411-419. [CrossRef]

37. ASTM (American Society of Testing and Materials). Petroleum Products, Lubricants, and Fossil Fuels: Gaseous Fuels, Coal, and Coke; ASTM International: Conshohocken, PA, USA, 2016.

38. Grossmann, R.B.; Reinsch, T.G. Bulk density and linear extensibility: Core method. In Methods of Soil Analysis:Part 4 Physical methods, SSSA Book Series 5.4; Dane, J.H., Topp, G.C., Eds.; Soil Science Society of America: Madison, WI, USA, 2002; pp. 208-228.

39. Stone, K.C.; Bauer, P.J.; Sigua, G.C. Irrigation Management Using an Expert System, Soil Water Potentials, and Vegetative Indices for Spatial Applications. Trans. ASABE 2016, 59, 941-948.

40. Howell, T.A. Enhancing Water Use Efficiency in Irrigated Agriculture. Agron. J. 2001, 93, 281. [CrossRef]

41. Zainul, A.; Koyro, H.-W.; Huchzermeyer, B.; Gul, B.; Khan, M.A. Impact of a biochar or a compost-biochar mixture on water relation, nutrient uptake and phytosynthesis of Phragmites karka. Pedosphere 2017. [CrossRef]

42. Hansen, V.; Hauggaard-Nielsen, H.; Petersen, C.T.; Mikkelsen, T.N.; Müller-Stöver, D. Effects of gasification biochar on plant-available water capacity and plant growth in two contrasting soil types. Soil N.a. 2016, 161, 1-9. [CrossRef]

43. Güereña, D.; Lehmann, J.; Hanley, K.; Enders, A.; Hyland, C.; Rhia, S. Nitrogen dynamics following field application of biochar in a temperate North American maize-based production system. Plant Soil 2013, 365, 239-254. [CrossRef]

44. Lamb, M.C.; Sorensen, R.B.; Butts, C.L. Crop response to biochar under differing irrigation levels in the southeastern USA. J. Improv. 2018, 32, 305-317. [CrossRef]

45. Major, J.; Rondón, M.; Molina, D.; Riha, S.J.; Lehmann, J. Maize yield and nutrition during 4 years after biochar application to a Colombian savanna oxisol. N.a. Soil 2010, 333, 117-128. [CrossRef] 
46. Van Zwieton, L.; Kimber, S.; Morris, S.; Chan, K.Y.; Downie, A.; Rust, J.; Joseph, S.; Cowie, A. Effects of biochar from slow pyrolysis of papermill waste on agronomic performance and soil fertility. Plant Soil 2010, 327, 235-246. [CrossRef]

47. Cornelissen, G.; Martinsen, V.; Shitumbanuma, V.; Alling, V.; Breedveld, G.D.; Rutherford, D.W.; Sparrevik, M.; Hale, S.E.; Obia, A.; Mulder, J. Biochar effect on maize yield and soil characteristics in five conservation farming sites in Zambia. Agronomy 2013, 3, 256-274. [CrossRef]

48. Lentz, R.D.; Ippolito, J.A. Biochar and Manure Affect Calcareous Soil and Corn Silage Nutrient Concentrations and Uptake. J. Qual. 2012, 41, 1033. [CrossRef] [PubMed]

49. Heckman, J.R.; Kamprath, E.J. Potassium Accumulation and Corn Yield Related to Potassium Fertilizer Rate and Placement. Soil Sci. Soc. J. 1992, 56, 141. [CrossRef]

50. Davis, J.G.; Walker, M.E.; Parker, M.B.; Mullinix, B. Long-Term Phosphorus and Potassium Application to Corn on Coastal Plain Soils. jpa 1996, 9, 88. [CrossRef]

51. US Climate Data. Climate for Florence-South Carolina and Weather Averages. Available online: https://www. usclimatedata.com/climate/Florence/south-carolina/united-states/ussc0113 (accessed on 26 March 2019).

52. Carr, T.; Yang, H.; Ray, C. Temporal Variations of Water Productivity in Irrigated Corn: An Analysis of Factors Influencing Yield and Water Use across Central Nebraska. PLOS ONE 2016, 11, e0161944. [CrossRef] [PubMed]

53. Novak, J.; Sigua, G.; Watts, D.; Cantrell, K.; Shumaker, P.; Szogi, A.; Johnson, M.G.; Spokas, K. Biochars impact on water infiltration and water quality through a compacted subsoil layer. Chemosphere 2016, 142, 160-167. [CrossRef] [PubMed]

54. Kissel, D.E.; Sonan, L. Soil Test Handbook for Georgia, Special Bulletin 62; University of Georgia: Athens, GA, USA, 2011; pp. 1-100.

55. Bohn, H.; McNeal, B.; O'Connor, G. Soil Chemistry; John Wiley \& Sons: New York, NY, USA, 1979; pp. 1-329.

56. Marschner, H. Mineral Nutrition of Higher Plants, 2nd ed.; Academic Press: San Diego, CA, USA, 1995; pp. 1-889.

57. Karlen, D.L.; Sadler, E.J.; Camp, C.R. Dry Matter, Nitrogen, Phosphorus, and Potassium Accumulation Rates by Corn on Norfolk Loamy Sand1. Agron. J. 1987, 79, 649. [CrossRef]

58. Clemson University Soil Testing Laboratory. Soil Test Rating System. 2019. Available online: https://www. clemson.edu/public/regulatory/ag-srvc-lab/soil-testing/pdf/rating-system.pdf (accessed on 26 March 2019). 